\title{
Conserved RxLR Effectors From Oomycetes Hyaloperonospora arabidopsidis and Phytophthora sojae Suppress PAMP- and Effector-Triggered Immunity in Diverse Plants
}

\author{
Devdutta Deb, ${ }^{1}$ Ryan G. Anderson, ${ }^{1}$ Theresa How-Yew-Kin, ${ }^{1}$ Brett M. Tyler, ${ }^{2}$ and John M. McDowell ${ }^{1,+}$ \\ ${ }^{1}$ Department of Plant Pathology, Physiology and Weed Science, Virginia Tech, Blacksburg, VA, 24061-0329, U.S.A.; ${ }^{2}$ Center for \\ Genome Research and Biocomputing, and Department of Botany and Plant Pathology, Oregon State University, Corvallis, OR \\ 97331, U.S.A.
}

Accepted 31 October 2017.

\begin{abstract}
Effector proteins are exported to the interior of host cells by diverse plant pathogens. Many oomycete pathogens maintain large families of candidate effector genes, encoding proteins with a secretory leader followed by an RxLR motif. Although most of these genes are very divergent between oomycete species, several genes are conserved between Phytophthora species and Hyaloperonospora arabidopsidis, suggesting that they play important roles in pathogenicity. We describe a pair of conserved effector candidates, HaRxL23 and PsAvh73, from $H$. arabidopsidis and P. sojae respectively. We show that $H a R x L 23$ is expressed early during infection of Arabidopsis. HaRxL23 triggers an ecotype-specific defense response in Arabidopsis, suggesting that it is recognized by a host surveillance protein. HaRxL23 and PsAvh73 can suppress pathogen-associated molecular pattern (PAMP)-triggered immunity (PTI) in Nicotiana benthamiana and effector-triggered immunity (ETI) in soybean. Transgenic Arabidopsis constitutively expressing HaRxL23 or PsAvh73 exhibit suppression of PTI and enhancement of bacterial and oomycete virulence. Together, our experiments demonstrate that these conserved oomycete RxLR effectors suppress PTI and ETI across diverse plant species.
\end{abstract}

Oomycete pathogens have evolved sophisticated mechanisms to avoid or suppress host immune responses (Jiang and Tyler 2012; Kamoun et al. 2015). One of the most destructive genera of oomycetes is Phytophthora, which is composed of over 120 species that cause important diseases on many dicot crops (Erwin and Ribiero 1996). For example, Phytophthora infestans, the causative agent of potato late blight disease, triggered the Great Irish Famine from 1845 to 1849 and remains one of the most destructive pathogens of potato and tomato today. Downy mildew pathogens comprise a sister group to the Phytophthora genus (Thines 2014), and some analyses actually place them within the genus (Ye et al. 2016). Downy mildews are obligate parasites and cause destructive diseases on grape, lettuce, cucurbits, and other crops (Gisi 2002; Lucas et al. 1995). Overall, it is difficult to control oomycete diseases because they rapidly evolve to overcome fungicides or genetic resistance in the host (Fry 2008).

${ }^{\dagger}$ Corresponding author: John M. McDowell; E-mail: johnmcd@vt.edu

*The $\boldsymbol{e}$-Xtra logo stands for "electronic extra" and indicates that eight supplementary figures and two supplementary tables are published online.

(c) 2018 The American Phytopathological Society
Plants maintain a robust, multilayered immune system that enables them to resist most pathogens (Dodds and Rathjen 2010). The primary layer of plant immunity is activated by the recognition of conserved microbial molecules, referred to as pathogen (or microbe)-associated molecular patterns (PAMPs or MAMPs). Such PAMPs or MAMPs are recognized by plant pattern recognition receptors, thereby activating PAMP-triggered immunity (PTI) (Chisholm et al. 2006; Jones and Dangl 2006). Outputs of PTI include production of reactive oxygen species, callose deposition, activation of MAPK signaling cascades, and induction of defense genes (Boller and Felix 2009; Couto and Zipfel 2016; Macho and Zipfel 2014).

Pathogens deliver effector proteins to the exterior and interior of plant cells to interfere with immune responses (Hogenhout et al. 2009; Toruño et al. 2016). Effectors have been extensively studied in bacterial phytopathogens, which use type III secretion (T3S) to deliver 20 to 40 effector proteins to the interior of plant cells (Chang et al. 2014; Feng and Zhou 2012). Some pathogen effectors are recognized by host resistance $(\mathrm{R})$ proteins directly or indirectly, activating effector-triggered immunity (ETI) (Chisholm et al. 2006; Cui et al. 2015; Jones and Dangl 2006; van der Hoorn and Kamoun 2008). ETI often culminates in plant cell death at the site of infection (often termed the hypersensitive response [HR]), accompanied by production of reactive oxygen species, antimicrobial metabolites, and induction of defense genes (Dodds and Rathjen 2010). Pathogens can counteract ETI through deletion or silencing of Avr/effector genes to avoid $\mathrm{R}$ protein recognition or by suppressing downstream signaling events (Feng and Zhou 2012).

Phytophthora species and downy mildew pathogens are thought to secrete effectors from intracellular feeding structures called haustoria as well as from intercellular hyphae (Torto et al. 2003; Wang et al. 2017; Whisson et al. 2007). Based on their localization in the host, effectors are broadly categorized as apoplastic or cytoplasmic (Birch et al. 2006; Kamoun 2006; Qutob et al. 2006). Bioinformatic approaches have led to the identification of many effector candidates in the genomes of oomycetes (Adhikari et al. 2013; Baxter et al. 2010; Fabro et al. 2011; Haas et al. 2009; Jiang et al. 2008; Lamour et al. 2012; Lévesque et al. 2010; Savory et al. 2012; Tian et al. 2011; Tyler et al. 2006; Win et al. 2012). Some of the most widely studied oomycete effector proteins are defined by the presence of a signal peptide (SP) in the $\mathrm{N}$ terminus followed by the amino acid motifs RxLR (arginine [Arg]-any amino acidleucine-Arg) and EER (glutamate [Glu]-Glu-Arg)) within the first 100 or so residues of the $\mathrm{N}$ terminus (Rehmany et al. 2005; Whisson et al. 2007). The SP presumably enables secretion of the 
effectors outside the pathogen. The RxLR motif has been proposed to facilitate translocation of the effectors to the interior of host cells and this is a subject of active investigation (Jiang and Tyler 2012; Petre and Kamoun 2014). The SP and RxLR are typically followed by a C-terminal domain that mediates the specific function of the effector protein inside the host cell (e.g., interaction with a host protein). Many RxLR effectors also contain conserved C-terminal motifs, called W, Y, or L, based on canonical tryptophan $(\mathrm{W})$, tyrosine $(\mathrm{Y})$, and leucine $(\mathrm{L})$ residues. These motifs are generally arranged as repeats and have been shown to be required for defense suppression activity or recognition by R proteins (Dou et al. 2008; Jiang et al. 2008). Structural studies have demonstrated that these domains form a core $\alpha$-helical fold that can accommodate structural changes (mutation of surface residues, repeat copy number variation, indels) that can facilitate coevolution with the host (Boutemy et al. 2011; Win et al. 2012).

Phytophthora spp. and downy mildew pathogens maintain large superfamilies of predicted RxLR proteins, ranging in size from over 100 members (e.g., Hyaloperonospora arabidopsidis) to over 500 (e.g., P. infestans) (Jiang and Tyler 2012). Recent studies have revealed that many RxLR effectors are capable of suppressing plant immunity (Anderson et al. 2015). Specific targets of RxLR proteins are also coming into focus. For example, $P$. infestans RxLR effector Avr3a interacts with the Nicotiana benthamiana U-box protein CMPG1, and this interaction appears to promote virulence by stabilizing CMPG1 (Bos et al. 2010; González-Lamothe et al. 2006). P. infestans PexRD2 interferes with mitogen-activated protein kinase (MAPK) signaling. P. infestans Pi03192 targets NAC transcription factors (McLellan et al. 2013). H. arabidopsidis HaRxL44 targets a subunit of the mediator transcriptional regulatory complex to manipulate plant hormone crosstalk (Caillaud et al. 2012). These and other studies suggest that RxLR effectors can target a variety of plant regulatory proteins; this point is underscored by the identification of plant-pathogen protein interactomes, which suggest that effectors from oomycetes, fungi, and bacteria converge onto highly connected hubs in the plant immune network (Mukhtar et al. 2011; Weßling et al. 2014). However, these studies are only the first steps toward a full understanding of the mechanisms and evolution of host manipulation via RxLR proteins.

Hyaloperonospora arabidopsidis is an obligate biotroph and is the causative agent of Arabidopsis downy mildew (Coates and Beynon 2010; Holub 2008). The genome of the H. arabidopsidis isolate Emoy2 contains at least 134 RxLR candidate effector genes (HaRxL genes) (Baxter et al. 2010; McDowell 2014).
Very few of the $H$. arabidopsidis effectors have recognizable homologs in Phytophthora species (Baxter et al. 2010). However, a few candidate effector genes are syntentic and conserved between these distantly related oomycetes (e.g., HaRxL96 [Anderson et al. 2012]) We anticipate that analysis of conserved effectors will reveal virulence functions that are important for Phytophthora and downy mildew plant pathogens, leading to the identification of conserved plant targets.

In this study, we characterize a conserved, orthologous pair of effectors from $H$. arabidopsidis and Phytophthora sojae, HaRxL23 and PsAvh73. HaRxL23 is expressed early during infection and triggers an ecotype-specific defense response in Arabidopsis, suggesting that it is a bona fide effector protein. Functional comparisons of HaRxL23 and PsAvh73 proteins revealed that both effectors have similar functional capabilities and can suppress immunity in diverse plant species.

\section{RESULTS}

\section{HaRxL23 and PsAvh73 are syntenic and share conserved functional domains.}

HaRxL23 is one of four high-confidence $H$. arabidopsidis RxLR candidate effector genes for which a homolog is present at syntenic loci in Phytophthora genomes (Baxter et al. 2010). Figure 1 illustrates the primary sequence conservation between HaRxL23 and homologous genes from $P$. sojae and $P$. infestans. All three genes contain a predicted SP at their N termini. The SP is followed by RLLR and RALR motifs in HaRxL23 and PsAvh73, respectively, followed by a short, acidic dEER-like motif. HaRxL23 and PsAvh73 each encode a single copy of the $\mathrm{W}$ and $\mathrm{Y}$ motifs that are found in many RxLR effectors and comprise a conserved protein fold (Win et al. 2012). W and Y motifs are typically highly variable but are unusually wellconserved among the members of the HaRxL23 and PsAvh73 family of orthologs (Boutemy et al. 2011; Jiang et al. 2008). No other motifs or subcellular localization signals could be discerned in the sequences of these effectors.

To assess allelic diversity at the HaRxL23 locus, we sequenced this gene in two additional isolates (Emco5 and Hiks1). In both isolates, the nucleotide sequence is identical to the reference sequence from the genome of $H$. arabidopsidis Emoy2. Similarly, it has been reported that the sequence of $P s A v h 73$ is monomorphic among four races that encompass the pathotype diversity of $P$. sojae in the United States (Förster et al. 1994; Wang et al. 2011). Thus, HaRxL23 and PsAvh73 are likely conserved within their respective species.

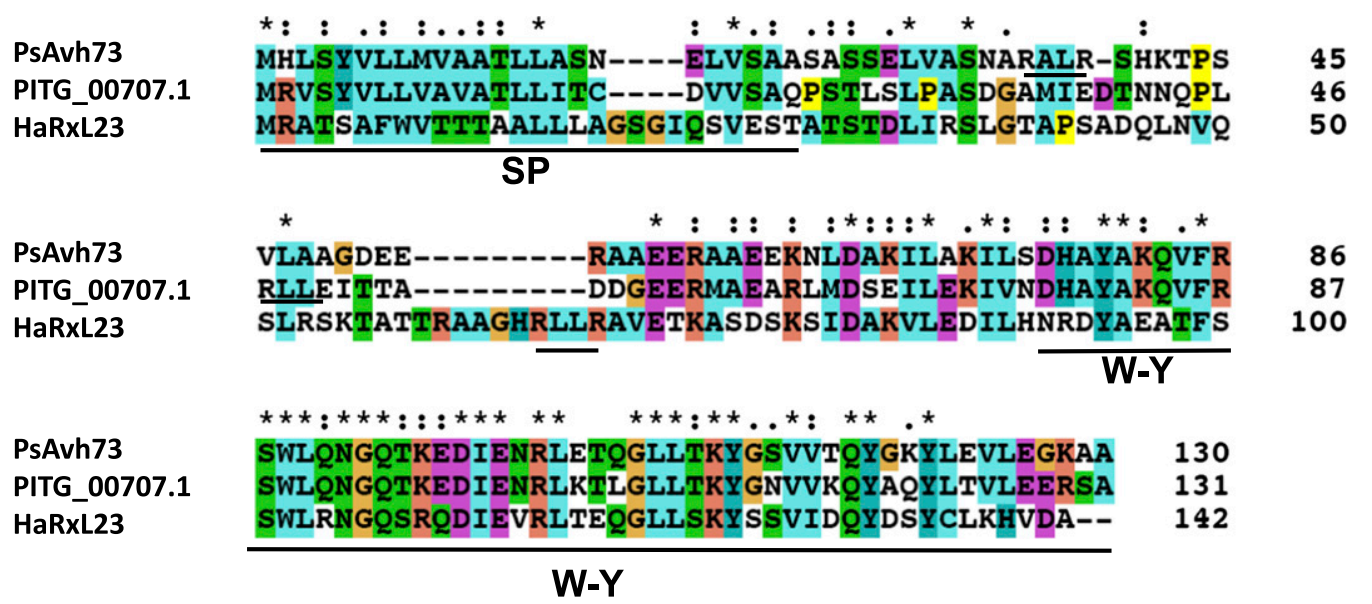

Fig. 1. Alignment of amino acid sequences from HaRxL23, PsAvh73, and Phytophthora infestans PITG_00707.1. The predicted signal peptide (SP), RxLR, and W-Y motifs are indicated. 
HaRxL23 is induced early during pathogen infection.

We tested whether HaRxL23 was induced during infection by virulent $H$. arabidopsidis. Four-week old Arabidopsis ecotype Oystese (Oy-1) plants were inoculated with a spore suspension from the virulent $H$. arabidopsidis isolate Emoy2. RNA was isolated from infected plant tissue over a time course, and the relative abundance of $H a R x L 23$ transcripts was assayed using quantitative real-time polymerase chain reaction (qRT-PCR). The abundance of HaRxL23 transcripts peaked at around $12 \mathrm{~h}$ postinoculation (hpi) (Fig. 2) and declined during the later timepoints, to a level lower than that observed in spores immediately after inoculation.

\section{HaRxL23 is recognized by Arabidopsis in an ecotype-specific manner.}

As another functional test for HaRxL23, we assayed whether it induces ETI in Arabidopsis. We screened 48 Arabidopsis accessions using the effector detector vector (EDV) system, in which oomycete effectors are delivered by Pseudomonas bacteria via T3S to the interior of Arabidopsis cells (Sohn et al. 2007). We used the Pseudomonas fluorescens strain EtHAn (effector to host analyzer), which is a nonpathogen of Arabidopsis, lacks discernable T3S effectors and contains a genetically engineered T3S system to deliver effectors of interest (Thomas et al. 2009). This approach ensured the exclusive delivery of our effector into the host, without complications from endogenous bacterial effectors. Equally important, EtHAn does not trigger disease symptoms in Arabidopsis, reducing complications of visual HR interpretation.

As a standard of comparison for a typical HR, we used Pseudomonas syringae pv. tomato DC3000 carrying AvrRpt2 in the resistant Arabidopsis ecotype Col-0 (Fig. 3A and B) (Sohn et al. 2007). We also used the $H$. arabidopsidis avirulence effector Atr13, which has been previously shown to trigger HR due to recognition of this effector by the RPP13 resistance protein (Allen et al. 2004). When delivered via the EtHAn/EDV system, Atr13 produced a typical leaf collapse phenotype, albeit weaker than that of AvrRpt2 delivered from P. syringae pv. tomato DC3000 (Fig. 3A and B) (Sohn et al. 2007).

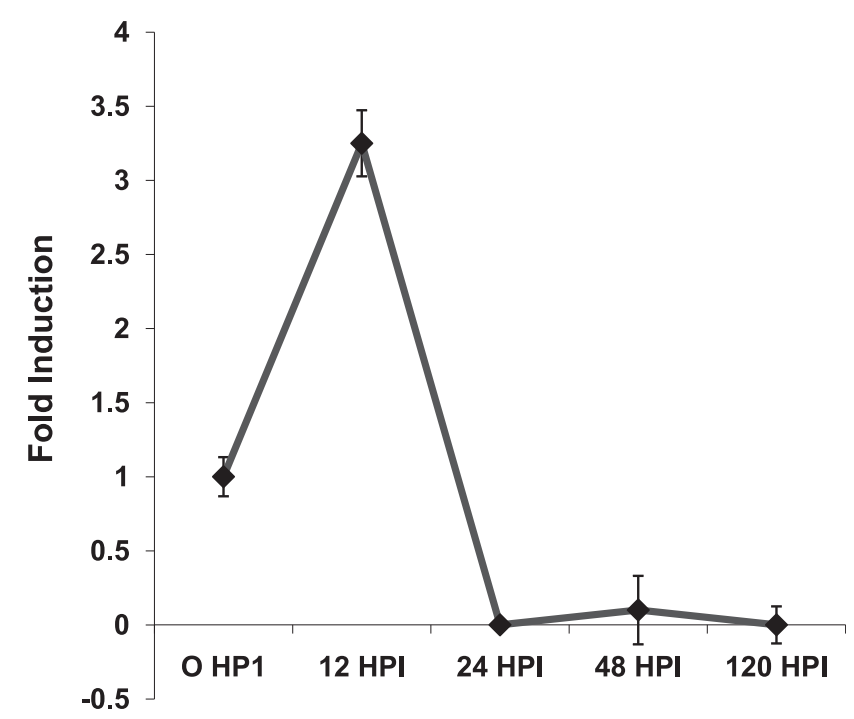

Fig. 2. HaRxL23 is induced at an early timepoint in Hyaloperonospora arabidopsidis infection. Arabidopsis Oy-1 plants were challenged with $5 \times 10^{4}$ spores of the virulent $H$. arabidopsidis isolate Emoy 2 per milliliter. HaRxL23 expression was assayed using quantitative, real-time polymerase chain reaction with primers specific for HaRxL23 over a time course, using the cDNA obtained at timepoints shown on the $x$ axis. Transcript abundance of HaRxL23 was measured relative to H. arabidopsidis Actin and is shown normalized to HaRxL23 abundance at the 0-h timepoint.
We inoculated $P$. fluorescens EtHAn expressing HaRxL23 onto 48 Arabidopsis ecotypes (Supplementary Table S2). We observed leaf collapse symptoms comparable to the two controls in the Arabidopsis ecotype Ei-4 (Fig. 3A and B). Two other Arabidopsis ecotypes, Ob-0 and Pla-1, also showed partial leaf collapse phenotypes in response to EtHAn (HaRxL23), indicative of a weak HR (Supplementary Fig. S2). We then examined the growth in ecotype Ei-4 of $P$. syringae pv. tomato DC3000 expressing HaRxL23 compared with P. syringae pv. tomato DC3000 containing an empty vector. We observed a fourfold reduction in bacterial growth in DC3000(HaRxL23) compared with DC3000 in Ei-4 (Fig. 3C). When ecotype Ei-4 was inoculated with Emoy2, the source of the allele of HaRxL23 used in these experiments, it proved resistant (Supplementary Figs. S5 and S6) consistent with the possibility of an $\mathrm{R}$ protein in Ei-4 that recognizes HaRxL23. These experiments indicate that HaRxL23 is recognized by the Arabidopsis immune system in an ecotype-specific manner, suggestive of gene-for-gene resistance and consistent with the hypothesis that HaRxL23 is an effector.

To test whether PsAvh73 has avirulence activity in Arabidopsis similar to HaRxL23, we inoculated P. fluorescens EtHAn expressing PsAvh73 onto the same 48 Arabidopsis ecotypes tested with HaRxL23. The HaRxL23-responsive ecotypes Ei-4 and Ob-0 also responded to PsAvh73, but the HR was much weaker. Pla-1 did not respond to PsAvh73, nor did any of the other tested ecotypes. Thus, PsAvh73 provoked a similar but weaker spectrum of resistance responses in our collection of Arabidopsis ecotypes.

HaRxL23 and PsAvh73 suppress programmed cell death (PCD) in $N$. benthamiana.

As a first test of whether HaRxL23 and PsAvh73 contribute to pathogen virulence, we assayed whether these effectors could suppress PCD, when transiently expressed in $N$. benthamiana via Agrobacterium-mediated delivery. Neither of the effectors could induce cell death when expressed by themselves in $N$. benthamiana (Fig. 4). We induced PCD by the $P$. infestans elicitin, Infestin 1 (INF1), which is a PAMP, or by the $P$. sojae RxLR effector PsAvh163. Both of these proteins trigger a strong HR in leaves of $N$. benthamiana (Anderson et al. 2012; Bos et al. 2006; Wang et al. 2011). Agrobacterium tumefaciens GV3101 containing binary T-DNA vectors with either CaMV35HaRxL23 or CaMV35-PsAvh73 were infiltrated into the leaves of $N$. benthamiana. These leaves were challenged, 24 or $48 \mathrm{~h}$ later, with CaMV35-INF1 or CaMV35-PsAvh163 via Agrobacteriummediated delivery. Five to 7 days later, we visually scored each infiltration site for cell death. We observed that INF1-induced cell death is suppressed by PsAvh73 (Fig. 4A) but not by HaRxL23. Both HaRxL23 and PsAvh73 suppressed PsAvh163induced cell death (Fig. 4B). An Agrobacterium strain with CaMV35-YFP (yellow fluorescent protein) served as the control for this experiment and did not suppress cell death triggered by INF1 or PsAvh163. These results suggested that these two effectors were also capable of suppressing PCD in $N$. benthamiana, similar to other bacterial and oomycete effectors (Alfano 2009; Cabral et al. 2011; Wang et al. 2011). The cell death-suppressive activity of PsAvh73 was further supported by Wang et al. (2011), who, based on coexpression in Nicotiana benthamiana, demonstrated that PsAvh73 is a strong suppressor of cell death triggered by mammalian BAX.

\section{HaRxL23 and PsAvh73 suppress PCD in soybean.}

To assess whether HaRxL23 and PsAvh73 could contribute to virulence in soybean, we used a biolistic assay for suppression of ETI (Kale and Tyler 2011). Avr4/6 is an RxLR effector from $P$. sojae that triggers an HR in soybean cultivars with the RPS4 or 
RPS6 resistance genes (Kale and Tyler 2011). When Avr4/6 is cobombarded with a $\beta$-glucuronidase (GUS) into leaves with RPS4 or RPS6, PCD from a HR elicited by Avr4/6 reduces the number of blue spots visualized, compared with control leaves bombarded only with the GUS gene plus an empty vector (Supplementary Fig. S3). Co-bombardment with a third gene that suppresses PCD will restore the viability of bombarded cells, which manifests itself as a larger number of GUS-positive spots in the leaves bombarded with the effector (Dou et al. 2008). This assay allows for quantitative assessments of the ability of a candidate effector to suppress PCD. A second elicitor from $P$. infestans, CRN2, was also used as a cell-death inducer. CRN2 (crinkling and necrosis 2) is a necrosis-inducing effector protein and its ectopic expression results in cell death response in $N$. benthamiana, tomato, and soybean (Torto et al. 2003).

As expected, co-bombardment of GUS and Avr4/6 in RPS4 soybean significantly reduced the number of $G U S$-expressing cells up to $60 \%$, compared with leaves bombarded with the empty vector control instead of $A v r 4 / 6$ (Dou et al. 2010). However, a combination of GUS and Avr4/6 with HaRxL23 or $P s A v h 73$ restored the numbers of $G U S$-expressing viable cells (Fig. 5A). Similarly, we observed a $65 \%$ decrease of $G U S$ expressing viable cells in tissue bombarded with $C R N 2$, relative to control samples. CRN2-induced cell death was reduced when HaRxL23 or PsAvh73 was included in the bombardment (Fig. 5B). Thus, both HaRxL23 and PsAvh73 can suppress cell death induced by either Avr4/6 or CRN2 in soybean.

\section{HaRxL23 and PsAvh73 enhance susceptibility to virulent $H$. arabidopsidis.}

To test whether HaRxL23 and PsAvh73 could contribute to virulence in Arabidopsis, we expressed both effectors as stable transgenes and evaluated PTI and ETI compared with nontransgenic control plants (Munkvold and Martin 2009). This method has been previously used to characterize several bacterial and oomycete effectors (Fabro et al. 2011; Hauck et al. 2003;
Munkvold and Martin 2009; Nomura et al. 2006). We generated Arabidopsis Col-0 lines expressing either HaRxL23 or PsAvh73 under the control of the Cauliflower mosaic virus (CaMV) $35 \mathrm{~S}$ promoter. We obtained several independent, single insertion-locus lines. Transgene mRNA abundance was verified by qRT-PCR in each experimental line (Supplementary Fig. S4). Homozygous lines with different transcript abundance were selected for all subsequent experiments, to evaluate potential quantitative phenotypic effects. We observed little phenotypic variation between independent transformants suggesting that transgene expression levels were not a significant variable affecting the phenotypes arising from transgene expression.

We first tested whether in planta overexpression of the two effectors suppressed basal resistance against virulent $H$. arabidopsidis. Wild-type and transgenic seedlings were inoculated with spores from virulent $H$. arabidopsidis Emco5, and pathogen growth was quantified by counting sporangiophores at 7 days after inoculation. Representative Arabidopsis lines constitutively expressing either HaRxL23 or PsAvh73 showed enhanced susceptibility to virulent $H$. arabidopsidis isolate Emco5, compared with wild-type Col-0 plants (Fig. 6). This result suggests that both effectors are capable of suppressing basal resistance to virulent $H$. arabidopsidis in Arabidopsis.

Next, we tested whether the Col:HaRxL23 lines were more susceptible to the avirulent $H$. arabidopsidis isolate Emoy2, which is recognized in Col- 0 by the resistance gene RPP4 (van der Biezen et al. 2002). We observed no differences between control Col-0 and transgenic HaRxL23 lines in Emoy2 sporulation or in HR cell death. This result suggests that HaRxL23 does not interfere with ETI-mediated by RPP4.

\section{HaRxL23 and PsAvh73 suppress callose formation in stably transformed Arabidopsis in response} to Pseudomonas syringae $\mathrm{DC} 3000(\triangle C E L)$ mutant.

Because $H$. arabidopsidis makes intimate contact with host cell walls during pathogenesis, we hypothesized that $H$. arabidopsidis
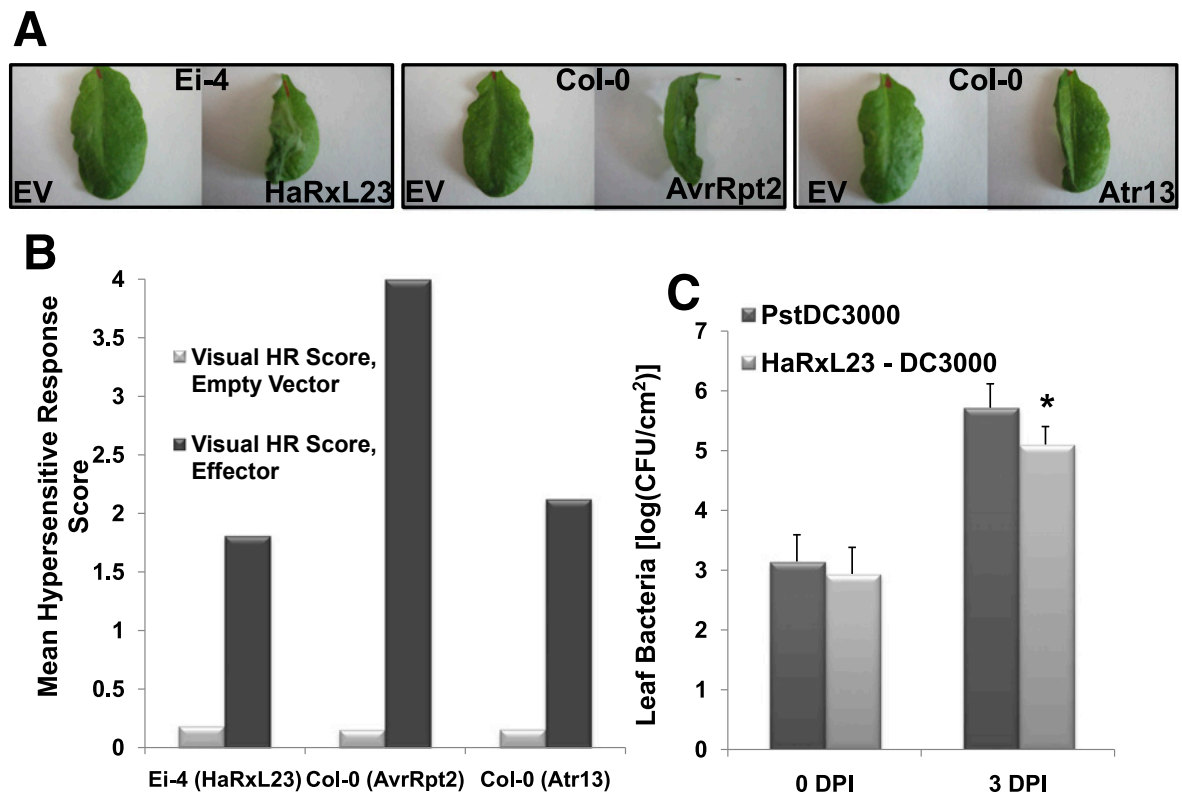

Fig. 3. HaRxL23 is recognized in the host in an ecotype-specific manner when delivered by bacteria. A, Leaves of Arabidopsis Ei-4 or Col-0, infiltrated with a $1 \times 10^{8} \mathrm{CFU} / \mathrm{ml}$ Pseudomonas fluorescens (EtHAn) suspension carrying an empty vector (EV), HaRxL23, Pseudomonas syringae effector gene AvrRpt2, or Hyaloperonospora arabidopsidis effector gene Atr13. Hypersensitive response (HR) symptoms were visually monitored over a period of $24 \mathrm{~h}$ and images were taken $24 \mathrm{~h}$ after inoculation. B, HR score: 4, complete leaf collapse, 3, partial leaf collapse, 2, leaf curling, 1, partial leaf curling, and 0, no change compared with the EV control. The experiment was repeated four times with similar results. C, Pseudomonas syringae pv. tomato DC3000 (HaRxL23) multiplication in leaves of Arabidopsis ecotype Ei-4 plants syringe-infiltrated with a suspension of $5 \times 10^{5} \mathrm{CFU} / \mathrm{ml}$. Bacterial populations were determined at day 0 and day 3 after inoculation. An asterisk (*) indicates $P<0.1 ; t$ test comparisons representing significant differences with $P$. syringae pv. tomato DC3000. Error bars indicate standard error of six independent leaf samples tested at the same time. This experiment was repeated three times with similar results. 
effectors may function to suppress cell wall-based defenses, such as callose deposition. Callose is a $\beta-1,3$ glucan that is deposited between the cell wall and cell membrane near the invading pathogen and is a quantitative proxy for measuring the Arabidopsis PTI response (Hauck et al. 2003). In these experiments, we quantified callose depositions induced in response to infiltration with the $P$. syringae mutant DC3000( $\Delta$ CEL). This strain contains deletions of at least four effector genes that are conserved among $P$. syringae strains resulting in dramatically reduced virulence in tomato and Arabidopsis and extensive callose deposits in the host plant (DebRoy et al. 2004; Sohn et al. 2007).

Accordingly, we observed extensive callose deposition in wild-type Arabidopsis Col-0 plants when syringe-infiltrated with the $\triangle$ CEL mutant (Fig. 7A). Contrastingly, a reduction of 30 to $50 \%$ in callose deposits was observed in multiple lines of Arabidopsis plants constitutively expressing either HaRxL23 or PsAvh73 (Fig. 7). This degree of suppression is similar to other $H$. arabidopsidis effectors assayed elsewhere (Anderson et al. 2012; Fabro et al. 2011; Sohn et al. 2007).

Next, we tested whether the HaRxL23 and PsAvh73 transgenic plants were capable of enhancing the growth of the nonpathogen $P$. syringae pv. tomato DC3000( $\triangle$ CEL) mutant. Wild-type and transgenic plants were syringe-infiltrated with $P$. syringae pv. tomato $\mathrm{DC} 3000(\Delta \mathrm{CEL})$ and growth was assayed at 0 and 3 days postinfiltration. Transgenic lines expressing either HaRxL23 or PsAvh73 showed enhanced susceptibility to $P$. syringae pv. tomato DC3000( $\Delta \mathrm{CEL})$ (Supplementary Fig. S7) 3 days postinoculation (dpi), further demonstrating that both HaRxL23 and PsAvh73 disable PTI in Arabidopsis.

To confirm these results, we used the EDV system to deliver HaRxL23 and PsAvh73 from P. syringae pv. tomato DC3000 $(\triangle \mathrm{CEL})$. These strains were infiltrated into Arabidopsis Col0 and callose deposits were quantified. We observed that both effectors suppressed callose when delivered via the T3S, similar to their effects when expressed as plant transgenes (Supplementary Fig. S8). Since the concentration of effectors in the host cytoplasm is presumably low, this result indicates that the phenotypes observed in stably transformed plants are unlikely to be neomorphic artifacts of transgene overexpression.

\section{Stably transformed HaRxL23 suppress defense gene induction.}

We next tested whether HaRxL23 was capable of suppressing induction of defense genes in response to $H$. arabidopsidis. We used qRT-PCR to measure the transcript abundance of four defense marker genes in Col:35S-HaRxL23 seedlings infected
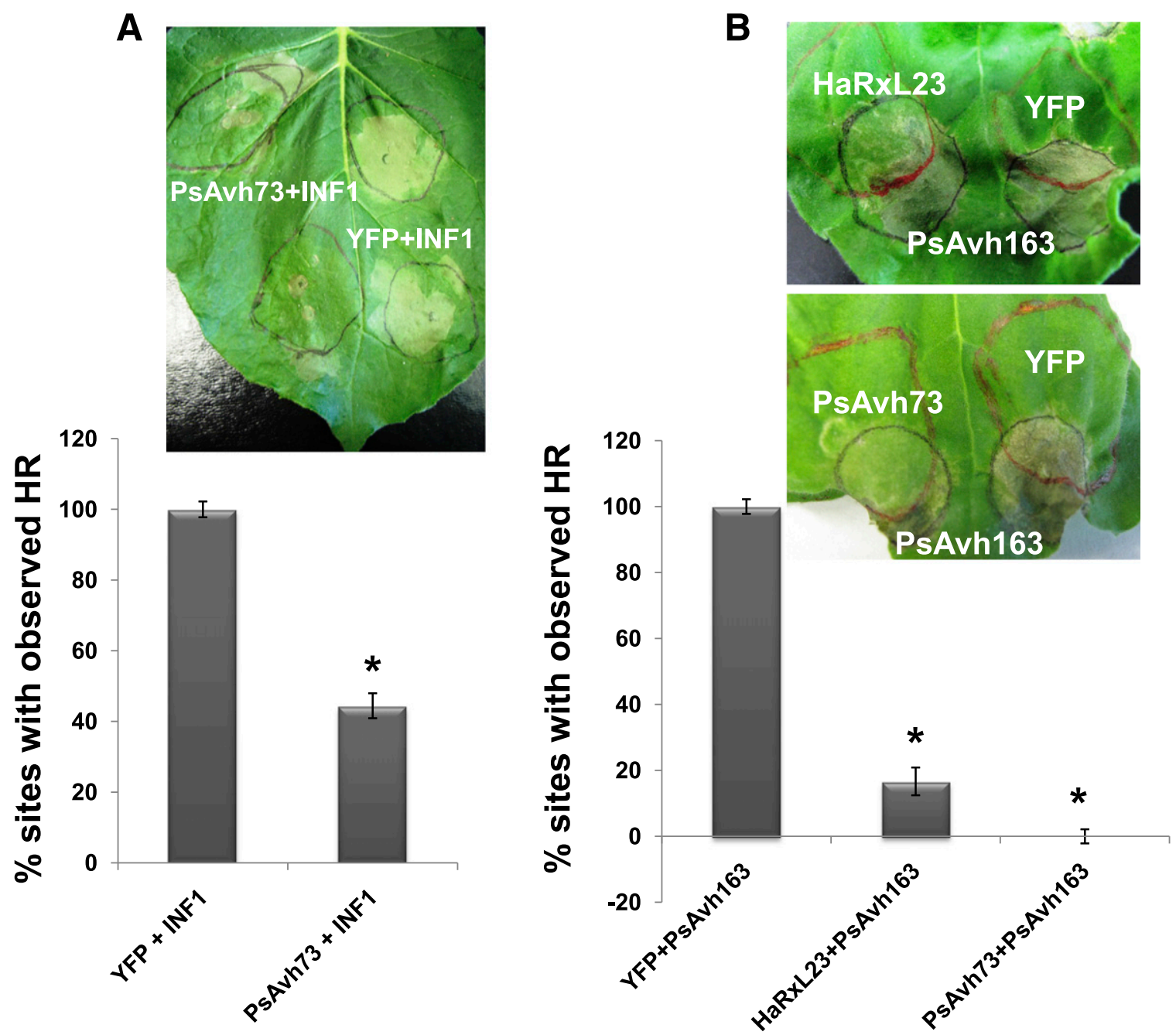

Fig. 4. HaRxL23 and PsAvh73 suppress programmed cell death in Nicotiana benthamiana. N. benthamiana leaves were infiltrated with Agrobacterium tumefaciens GV3101 containing HaRxL23, PsAvh73, or yellow fluorescent protein (YFP) and were challenged 2 days postinfiltration with A. tumefaciens GV3101 carrying either A, INF1 or B, PsAvh163. Cell-death symptoms were visually monitored over a period of 5 to 7 days. Graphs show the percentage of infiltration sites with macroscopic cell death. An asterisk (*) indicates $P<0.05, t$ test comparisons representing statistically significant differences with YFP. Error bars indicate standard error from four independent biological replicates. 
with avirulent $H$. arabidopsidis Emoy2. We assayed mRNA from four marker genes that were selected because they are transiently suppressed during early $H$. arabidopsidis infection: ACD6 (Accelerated cell death 6), PR-1 (Pathogenesis-related 1), AtMPK3 (Arabidopsis thaliana mitogen activated protein kinase 3), and WAKl (Wall-associated kinase 1) (Anderson et al. 2012; Eulgem et al. 2007). HaRxL23 suppressed induction of PR-1, MPK3, and ACD6 (Fig. 8). In contrast, induction of WAK1 was not suppressed by either effector, indicating defense gene-specific suppression. The induction profiles of individual genes varied to some degree between replicates, but we consistently observed decreased induction of defense marker genes (except for WAKl) in transgenic lines compared with the control plants. These results suggest that HaRxL23 intervenes early in the activation of defense.

\section{DISCUSSION}

Functional and mechanistic characterization of RxLR effectors is essential to understanding the molecular mechanisms of oomycete pathogenesis and host adaptation. In this study, we characterized a candidate RxLR effector from $H$. arabidopsidis, HaRxL23, and we included functional comparisons with its ortholog in P. sojae, PsAvh73. HaRxL23 is one of only four RxLR genes for which an ortholog is present at syntenic locations in sequenced genomes of Phytophthora pathogens (Baxter et al. 2010). Conserved effector genes represent potential opportunities for new insights into important mechanisms of virulence. Moreover, identification and breeding of resistance genes against conserved effector proteins can be utilized as an effective strategy for long-term durable resistance (Vleeshouwers and Oliver 2014).

Our first set of experiments was directed at testing the functions of the bioinformatically predicted effector genes. First, we demonstrated that HaRxL23 is induced early during infection in planta, consistent with a function as an effector. Data from RNAseq experiments (B. M. Tyler unpublished) indicate that $P s A v h 73$ is down-regulated 10 - to 20 -fold at $12 \mathrm{hpi}$, compared with in vitro-grown mycelia or to germinating cysts. It is possible that $P s A v h 73$ expression peaks before
12 hpi, concomitant with the short duration of the biotrophic state of P. sojae infection (Ma et al. 2015).

Additional evidence of effector function was provided by a screen for $R$ genes against HaRxL23 in Arabidopsis ecotypes. We used the EDV-based system to deliver HaRxL23 via T3S

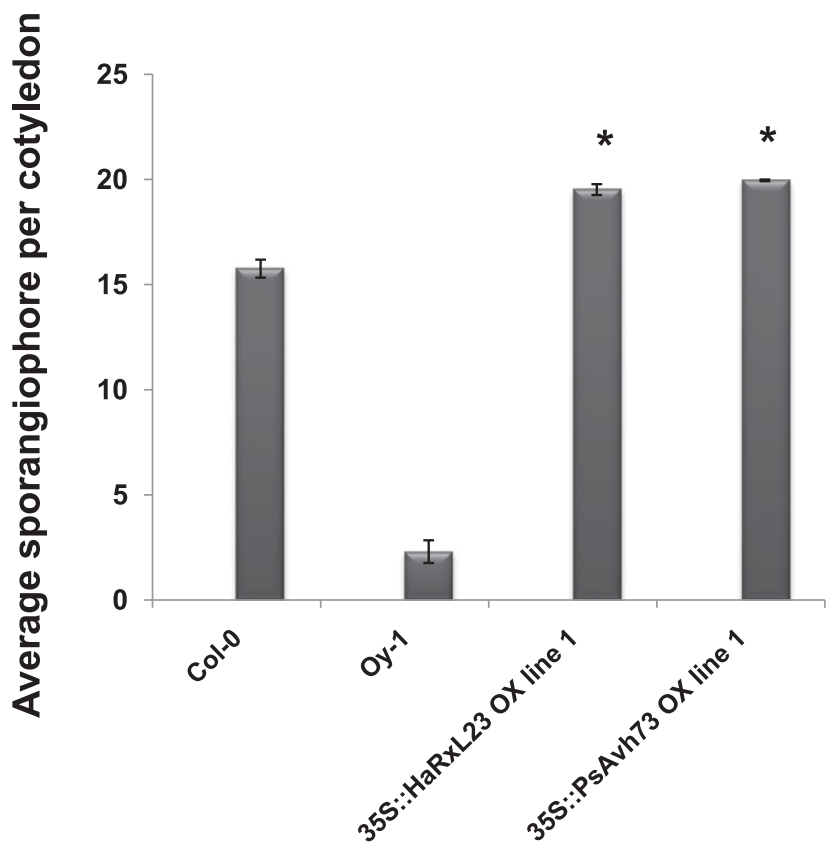

Fig. 6. HaRxL23 and PsAvh73 enhance susceptibility to virulent Hyaloperonospora arabidopsidis (Emco5). Ten- to 12-day-old transgenic Arabidopsis Columbia seedlings stably transformed with CaMV35S-HaRxL23 or CaMV35S-PsAvh73 were challenged with $5 \times 10^{4}$ spores of the virulent H. arabidopsidis isolate Emco5. Infection was quantified 7 days postinoculation by counting sporangiophores per cotyledon. Arabidopsis Col0 and $\mathrm{Oy}-1$ are controls for susceptibility and resistance to $H$. arabidopsidis Emco5, respectively. An asterisk (*) indicates $P<0.01 ; t$ test comparisons representing significant differences with Col-0. Error bars indicate standard error. This experiment was repeated three times with similar results.
A

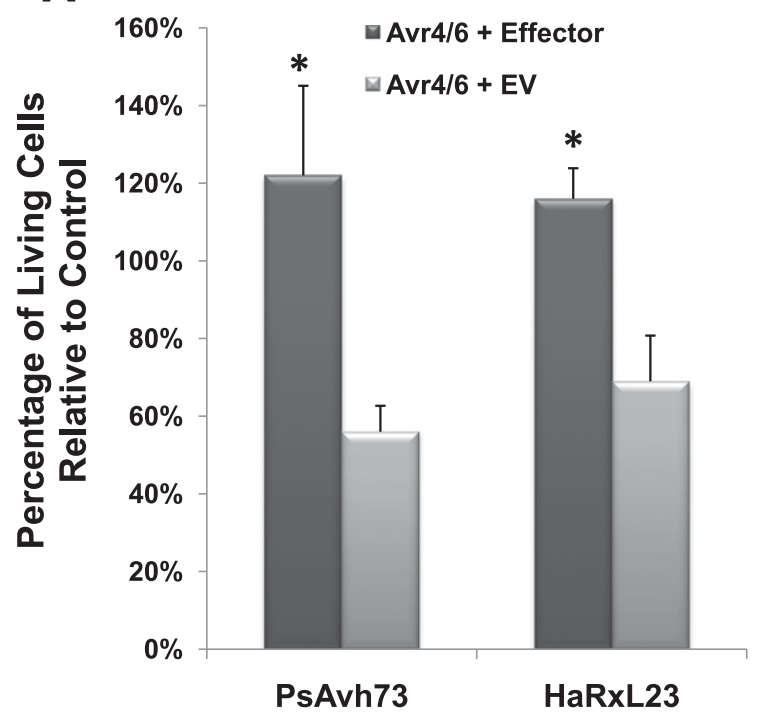

B

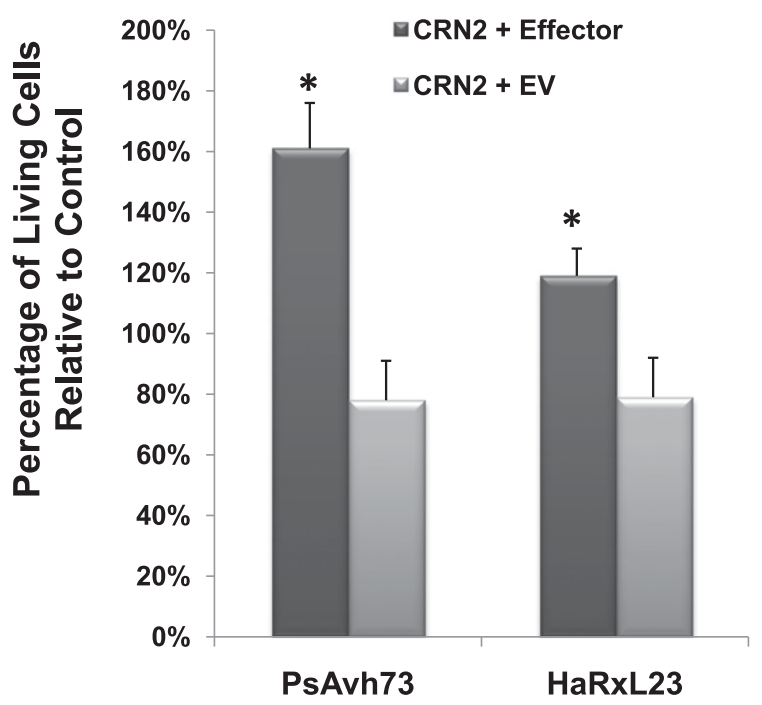

Fig. 5. HaRxL23 and PsAvh73 suppress programmed cell death in soybean. A plant-expression plasmid expressing A, CaMv35S-Avr4/6 or B, CaMv35S-CRN2 was co-bombarded, with plasmids containing the effectors CaMv35S-HaRxL23 or CaMv35S-PsAvh73 or the empty vector (EV), along with a vector expressing CaMv35S-GUS reporter gene, into soybean leaves. Leaves were stained for $\beta$-glucuronidase (GUS) activity, and cell viability was then estimated by counting blue spots under a dissecting microscope. The percentage of surviving cells was quantified relative to control leaves co-bombarded with a GUS plasmid and a second EV plasmid. An asterisk (*) indicates $P<0.05$, Wilcoxon rank sum test comparisons representing significant differences with the EV. Error bars indicate standard error from technical replicates. These experiments were repeated at least three times with similar results. 
from the nonpathogen $P$. fluorescens EtHAn. This general approach of delivering oomycete effectors from bacteria has been used previously to characterize known avirulence effectors from $H$. arabidopsidis and to rapidly screen for $R$ genes against novel H. arabidopsidis effectors (Fabro et al. 2011; Goritschnig et al. 2012; Sohn et al. 2007). This approach enabled us to identify an ecotype-specific HR phenotype that correlated with resistance to $H$. arabidopsidis, suggestive of gene-for-gene resistance triggered by HaRxL23. We believe that the ecotype-specificity of the resistance is due to an $R$ gene that is functional specifically in the Ei- 4 ecotype and, perhaps, also Ob- 0 and Pla- 1 . We note that recognition of HaRxL23 appears to be relatively rare, occurring in only three of the 48 ecotypes that we tested. This rarity is reminiscent of the RPP39 gene, which confers an HR-based response to the ATR39-1 RXLR effector from $H$. arabidopsidis when delivered by $P$. fluorescens. Only one of 83 tested ecotypes responded to ATR39-1 delivery (Goritschnig et al. 2012). RPP39 encodes a coiled coil-nucleotide binding-leucine-rich repeat protein.

The identification of a putative $R$ gene that recognizes HaRxL23 lays the groundwork for identifying the gene through map-based cloning, as reported by Goritschnig et al. (2012). An $R$ gene against HaRxL23 could be valuable for two reasons. First, molecular cloning of the $R$ gene might aid in identifying the virulence target if the $\mathrm{R}$ protein guards that target. Second, the $R$ gene could potentially be used as a source of resistance against oomycete pathogens of crop brassicas or, perhaps, even in more distantly related species. In this regard, it is interesting that PsAvh73 triggered a response, albeit weakly, in two of the same Arabidopsis ecotypes that recognized HaRxL23. Assuming that the same $R$ gene recognizes both effectors, its specificity for PsAvh73 or homologous effectors from other oomycete species could potentially be improved by mutagenesis (Harris et al. 2013; Segretin et al. 2014).

We next hypothesized that these two effector proteins might act as suppressors of defense pathways in divergent hosts, similar to our previous characterization of HaRxL96 and PsAvh163 (Anderson et al. 2012). We tested this hypothesis with studies involving transient assays in $N$. benthamiana, soybean, and Arabidopsis and with detailed characterization of stably transformed Arabidopsis. In $N$. benthamiana and soybean, both effectors could suppress cell death triggered by diverse oomycete elicitors. The functional capabilities of both proteins were similar, with the exception that cell death triggered by the Phytophthora PAMP INF1 could be suppressed by PsAvh73 but not by HaRxL23. H. arabidopsidis does not produce INF1-like elicitin proteins. In Arabidopsis, both effectors suppressed P. syringae pv. tomato $(\triangle \mathrm{CEL})$-induced callose deposition and promoted enhanced virulence of $P$. syringae. Moreover, both effectors conferred increased susceptibility to virulent $H$. arabidopsidis isolate Emco5, similar to other $H$. arabidopsidis effectors (Cabral et al. 2011; Fabro et al. 2011; Sohn et al. 2007). Interestingly, the effectors did not impair RPP4-dependent resistance to $H$. arabidopsidis Emoy2, suggesting that one or more of the targets of these effectors does not play an important role in the RPP4 pathway. However, the broad functionality of these effectors in divergent plant species, in response to diverse elicitors of PTI and ETI, indicates that one or more of the targets are conserved and play a central role in plant immunity.
A
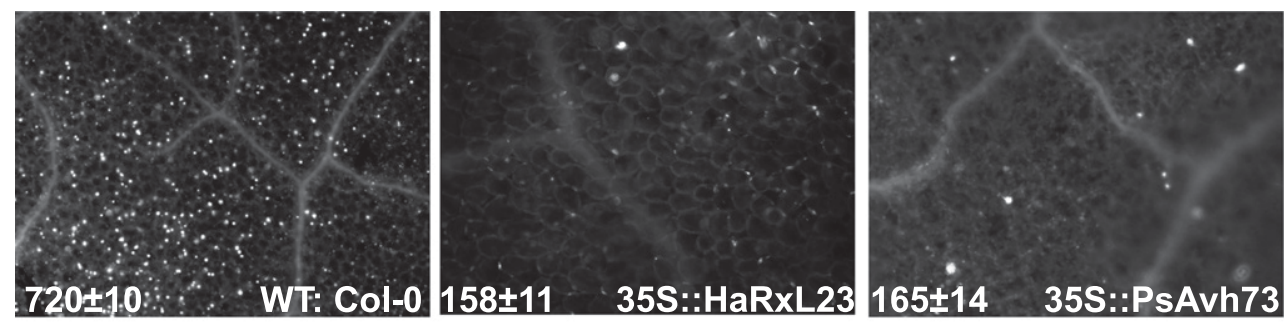

B
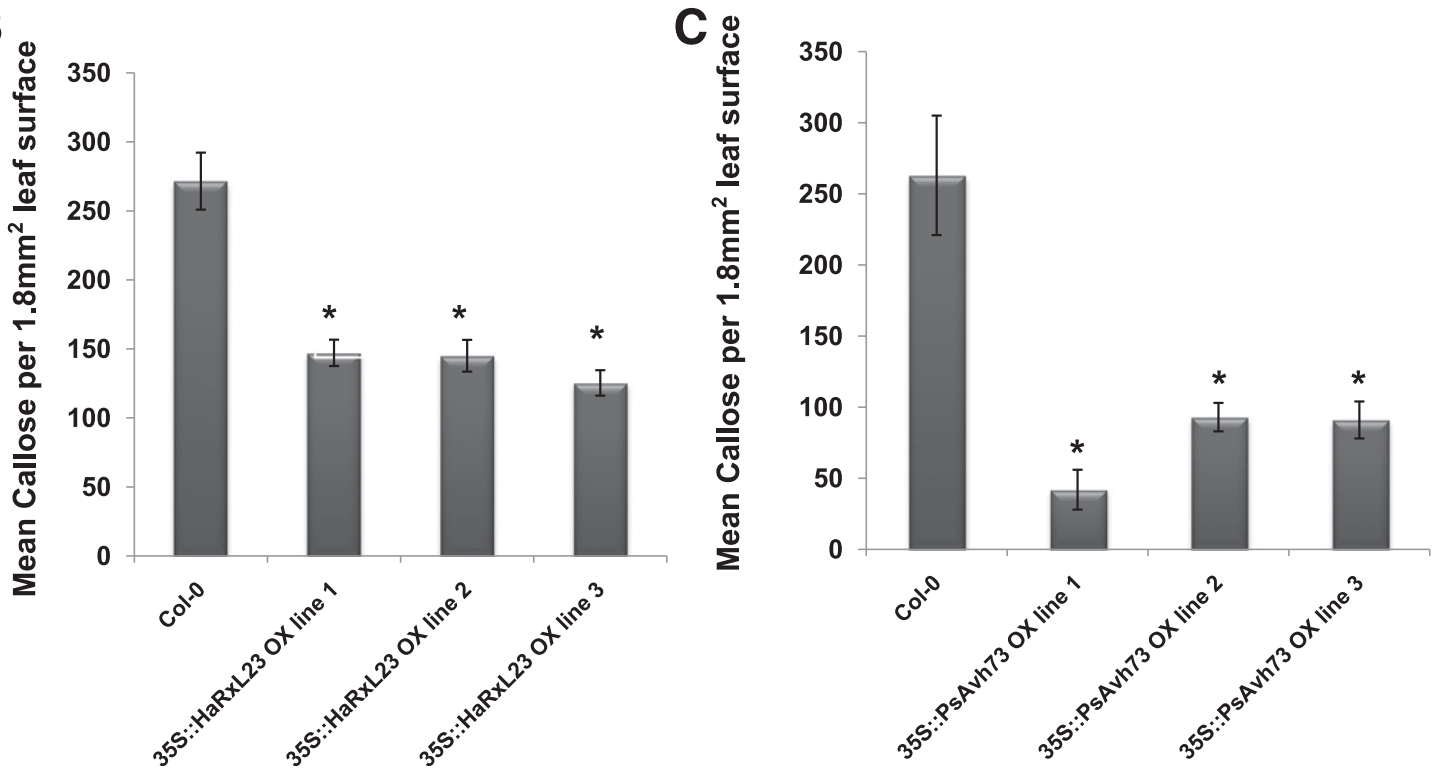

Fig. 7. HaRxL23 and PsAvh73 suppress callose formation in stably transformed Arabidopsis in response to Pseudomonas syringae DC3000( $\triangle$ CEL) mutant A, Four-week old transgenic Arabidopsis Columbia plants stably transformed with B, CaMV35S-HaRxL23 or C, CaMV35S-PsAvh73 were infiltrated with a $5 \times 10^{7} \mathrm{CFU} / \mathrm{ml}$ solution of $P$. syringae $\triangle \mathrm{CEL}$ mutant. Callose deposits were visualized by staining with aniline blue, and callose was quantified using the Autospots program (Cumbie et al. 2011). Four pictures per leaf from six leaves were analyzed from each transgenic and control line. An asterisk $(*)$ indicates $P<0.01 ; t$ test comparisons representing significant differences with Col-0. Error bars represent standard error of six independent leaf samples tested at the same time. This experiment was repeated three times with similar results. 
The identification of effector molecules from various eukaryotic pathogens enables us to draw parallels between prokaryotic and eukaryotic pathogens and helps to illuminate the extent to which these diverse pathogens share virulence strategies and target similar pathways of plant immunity. The next step in characterization of HaRxL23 and PsAvh73 is to identify their targets, thereby addressing the hypothesis that these effectors are targeting common proteins or processes in diverse hosts. The utility of studying conserved effectors is illustrated by previous studies of effectors from bacteria, e.g., the conserved effector locus (Collmer et al. 2000), and fungi, e.g., the SIX effectors from Fusarium spp. (Thatcher et al. 2012) and the Ecp6 effector from Cladosporium spp. (de Jonge et al. 2010). Mechanistic investigation of HaRxL23 and PsAvh73 is expected to yield similarly useful insights into the molecular basis of oomycete pathogenicity.

\section{MATERIALS AND METHODS}

Construction of expression plasmids.

HaRxL23 was amplified from genomic DNA extracted from Arabidopsis Oy-1 plants infected with $H$. arabidopsidis isolate Emoy2, using proofreading polymerase (Pfu; Invitrogen). Forward and reverse primers were designed to amplify from the SP cleavage site (HaRxL23 NOSP) with (HaRxL23 S) or without the stop codon (HaRxL23 NS), depending on the type of fusion. Similarly, PsAvh73 was amplified from P. sojae (isolate P6497) genomic DNA and forward (PsAvh73 NOSP) and reverse (PsAvh73 S or PsAvh73 NS) primers were designed.

For cloning into Gateway destination vectors, the sequence CACC was added at the $5^{\prime}$ end of the forward primer and PCR was performed using the genomic DNA as template. PCR products were gel-purified (Qiagen) and, finally, were recombined into pENTR-D-TOPO gateway entry vector following the manufacture's protocol (Invitrogen). This step was followed by transformation into Escherichia coli $\mathrm{DH} 5 \alpha$ competent cells. Kanamycin-resistant colonies were selected on agarose plates, followed by colony PCR with plasmid-specific M13 forward and M13 reverse primers. Colonies having the correct size insert were selected for plasmid purification and were confirmed by sequencing. The pENTR clone generated was then used to create Gateway expression plasmids using LR recombination (Invitrogen). For Agrobacterium-and Pseudomonas-mediated transient expression experiments, the pENTR clones of HaRxL23 and PsAvh73 were shuttled into pB2GW7 and pEDV6 by LR recombination (Invitrogen).

\section{Plant materials and growth conditions.}

Arabidopsis, soybean, and Nicotiana benthamiana were grown in Sunshine ProMix 1. For experiments involving H. arabidopsidis and Pseudomonas spp., Arabidopsis plants were grown in controlled growth chambers under short-day cycles ( $8 \mathrm{~h}$ of light and $16 \mathrm{~h}$ of dark and 150 to $200 \mu \mathrm{E} / \mathrm{m}^{2} \mathrm{~s}$ ) at $22^{\circ} \mathrm{C}$ and $60 \%$ relative humidity. For all other experiments,

\section{- Col-0 (RPP4) — Oy-1 (rpp4) —Col:35S:Ha23}

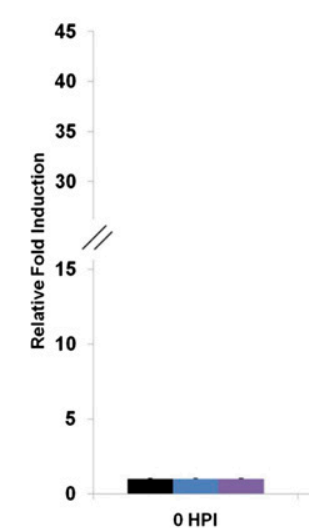

ACD6
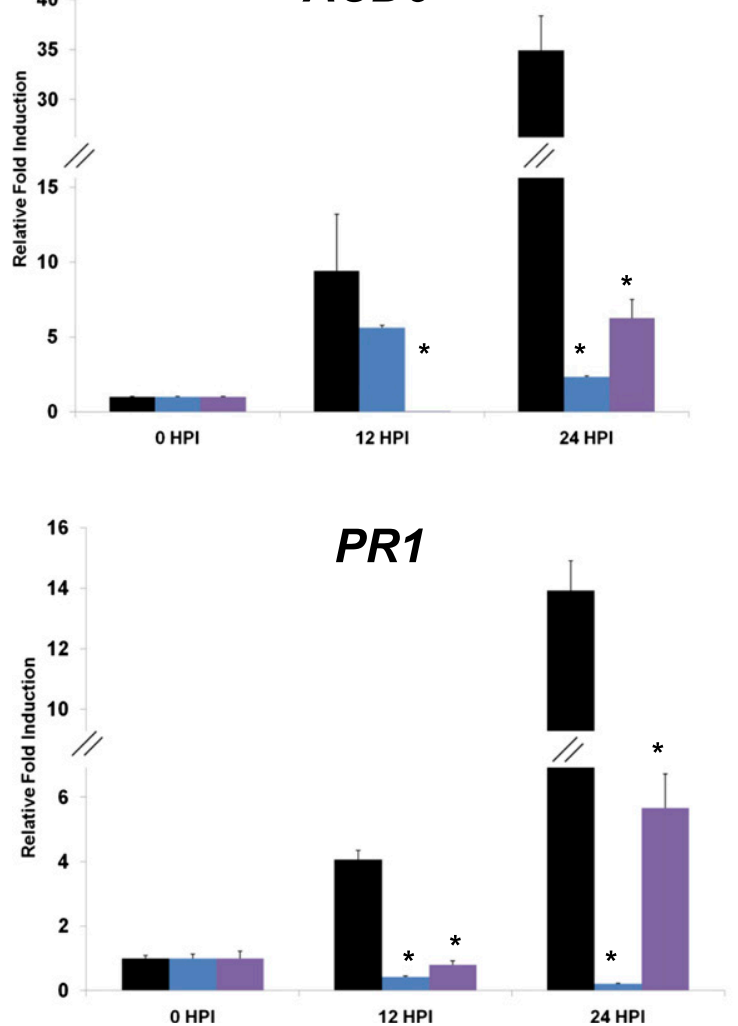
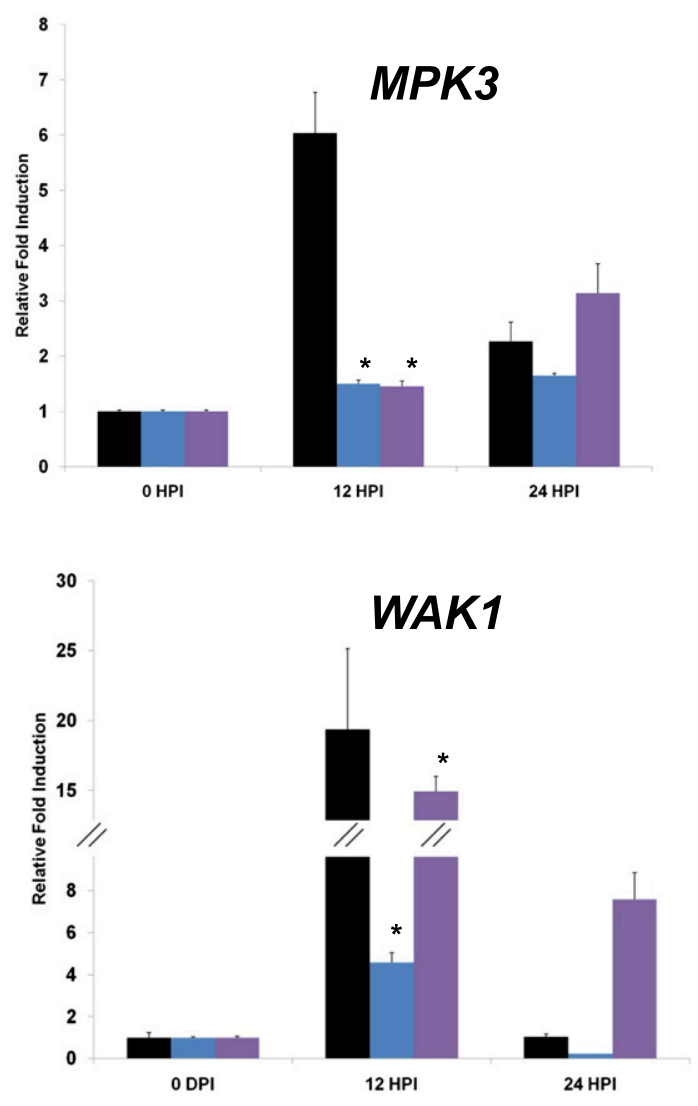

Fig. 8. Stably transformed HaRxL23 suppress defense gene induction. Ten- to 12-day-old Arabidopsis Col-0 and transgenic plants constitutively expressing HaRxL23 were inoculated with a $5 \times 10^{4}$ spores/ml suspension of the avirulent Hyaloperonospora arabidopsidis isolate Emoy2. Transcript abundance was measured using quantitative, real-time polymerase chain reaction at 0,12 , and $24 \mathrm{~h}$ postinoculation. Transcript abundance was normalized to AtActin2. An asterisk $(*)$ indicates $\mathrm{ddCt}$ (cycle threshold) values representing statistically significant $(P<0.05)$ differences with Col- 0 . This experiment was repeated four times with similar results. 
Arabidopsis, soybean, and $N$. benthamiana plants were grown under long-day cycles $(16 \mathrm{~h}$ of light and $8 \mathrm{~h}$ of dark, 90 to $100 \mu \mathrm{E} / \mathrm{m}^{2} \mathrm{~s}$ ) at $22^{\circ} \mathrm{C}$ and $60 \%$ relative humidity.

\section{Generation of transgenic Arabidopsis plants.}

Plants expressing effectors were generated by recombining open reading frames in pENTR with the destination binary vector pB2GW7 (Karimi et al. 2002), under the control of the CaMV $35 \mathrm{~S}$ promoter. The constructs were transferred to the A. tumefaciens GV3101 strain by electroporation and were transformed into Arabidopsis Col-0 by the floral dip method (Clough and Bent 1998). $\mathrm{T}_{1}$ generation transformants were selected using BASTA. For the $\mathrm{T}_{2}$ generation, 3:1 (BASTAresistant/BASTA-susceptible) segregating lines were tested for homozygosity in the $\mathrm{T}_{3}$ and $\mathrm{T}_{4}$ generation. Presence of the transgene was confirmed by PCR from genomic DNA and transcript abundance was quantified by reverse-transcriptase PCR from RNA isolated from transgenic plants. Three to five independent nonsegregating transgenic lines $\left(\mathrm{T}_{3}\right.$ or $\left.\mathrm{T}_{4}\right)$ displaying different mRNA abundance were used in the experiments.

\section{H. arabidopsidis inoculations.}

The $H$. arabidopsidis isolates Emoy2 and Emco5 were propagated and maintained in compatible Arabidopsis ecotypes Oy-1 and Ws-0, respectively (McDowell et al. 2011). Conidial suspensions of $5 \times 10^{4}$ spores $/ \mathrm{ml}$ were applied with a Preval spray unit and the plants were kept under short-day conditions. $H$. arabidopsidis disease assays and staining with trypan blue were performed as described (McDowell et al. 2011).

\section{Bacterial strains.}

The following bacterial strains were used in this study: E. coli $\mathrm{DH} 5 \alpha$, Pseudomonas syringae pv. tomato DC3000 wild type and $\triangle$ CEL (Alfano et al. 2000; Yuan and He 1996), Pseudomonas fluorescens Pf0-1 EtHAn carrying a functional T3S system (Thomas et al. 2009) and A. tumefaciens GV3101. $E$. coli and $A$. tumefaciens were grown in Luria-Bertani medium at $37^{\circ} \mathrm{C}$ and $28^{\circ} \mathrm{C}$, respectively, in liquid media or petri dishes with appropriate antibiotic selections. Pseudomonas strains were grown in King's B medium at $28^{\circ} \mathrm{C}$. Plasmids were introduced from $E$. coli DH5 $\alpha$ to wild-type or mutant $P$. syringae pv. tomato DC3000 and Pf0-1 strains by standard triparental matings, using E. coli RK600 as a helper strain.

\section{RNA extraction, reverse-transcriptase PCR, and real-time PCR.}

Total RNA was extracted from Arabidopsis tissue with TriSure reagent (Bioline). DNAse-treated RNA $(2 \mu \mathrm{g})$ was reversetranscribed using the OmniScript cDNA synthesis kit (Qiagen) and an oligo(dT) primer. For semiquantitative RT-PCR analysis, $1 \mu \mathrm{l}$ of cDNA was used per reaction and 40 and 35 PCR cycles were used to amplify effector targets and AtActin, respectively. PCR products were separated on $1 \%$ agarose gel in Tris-acetate-EDTA buffer. For RT-PCR analysis, samples were prepared by mixing cDNA template with SYBR green mastermix (Applied Biosystems) with the appropriate amount of primers and water. RT-PCR reactions were performed on an ABI 7300 device and the fold change was calculated relative to the 0 -dpi timepoint.

\section{Bacterial assays for HR, virulence, and callose suppression in Arabidopsis.}

For HR assays, five-week-old Arabidopsis leaves were syringeinfiltrated with a needle-less syringe with $1 \times 10^{8} \mathrm{CFU} / \mathrm{ml}$ suspensions in $10 \mathrm{mM} \mathrm{MgSO}_{4}$. A total of six plants, three leaves each, were infiltrated and visual scoring was performed $16 \mathrm{~h}$ later.

For bacterial growth assays, five-week-old Arabidopsis leaves were syringe-infiltrated with a needle-less syringe with $1 \times 10^{5}$
$\mathrm{CFU} / \mathrm{ml}$ suspensions in $10 \mathrm{mM} \mathrm{MgSO}$. Leaf discs were cored at 0 and 3 dpi, were surface-sterilized with $70 \%$ ethanol, and were homogenized using a mini-bead beater (Biospec Products). Serial dilutions were performed to count colony forming units. For each sample, three leaf discs were pooled three times per data point and bacterial growth was quantified by serial dilution and plating on selective media.

For callose suppression assays, whole leaves were harvested at $16 \mathrm{hpi}$, were treated with alcoholic lactophenol, and were stained with $0.01 \%$ (wt/vol) aniline blue stain in $\mathrm{K}_{2} \mathrm{HPO}_{4}$ buffer, as described previously (Sohn et al. 2007). Aniline blue-stained leaves were mounted on glass slides using $50 \%$ glycerol and were imaged with a Zeiss Axio Imager M1, using the filter settings for diamidino-2-phenylindole. Quantification of callose spots was performed using Autospots software (Cumbie et al. 2011).

\section{Transient assays in soybean.}

For transient assays in soybean, two-week-old leaves were transformed by particle bombardment using a mixture of plasmid DNA, following the modified BioRad PDS1000 gene gun protocol as described (Kale and Tyler 2011). The plasmid DNA mixtures were comprised of the effector, elicitor, and control setups. The effector setup comprised a mixture of $115 \mu \mathrm{g}$ of the effector DNA, $50 \mu \mathrm{g}$ of the elicitor DNA, and $50 \mu \mathrm{g}$ of GUS DNA, as described previously (Dou et al. 2008). The elicitor setup comprised a mixture of $70 \mu \mathrm{g}$ of the empty vector DNA, $50 \mu \mathrm{g}$ of the Avr4/6 or $C R N 2 \mathrm{DNA}$, and $50 \mu \mathrm{g}$ of GUS. The control mixture comprised $115 \mu \mathrm{g}$ of the empty vector DNA and $50 \mu \mathrm{g}$ of GUS plasmid DNA. Tungsten was prepared with the above mixtures as described earlier (Dou et al. 2008). Individual detached soybean leaves were transformed by particle bombardment using the tungsten preparation. After bombardment, the leaves were placed under controlled conditions of high humidity conditions in petri dishes at $8 \mathrm{~h}$ of light and $16 \mathrm{~h}$ of dark at $22^{\circ} \mathrm{C}$ for 2 to 3 days. Next, the leaves were stained with X-Gluc solution and were destained with $70 \%$ ethanol for 3 to 4 days. The number of living transformed cells was determined by counting GUS-expressing blue-colored cells under a dissecting microscope, using the Autospots software program (Cumbie et al. 2011). The percentage of surviving cells was quantified relative to the co-bombarded empty vector control. Statistical analyses were performed using the Wilcoxon rank sum test as described (Kale and Tyler 2011).

\section{Transient assays in $N$. benthamiana.}

Recombinant $A$. tumefaciens were grown, as described previously (Van der Hoorn et al. 2000), with the appropriate antibiotics. Overnight-grown Agrobacterium liquid cultures were centrifuged, and the pellets were resuspended in MMA induction buffer (10 mM MgCl $2,10 \mathrm{mM}$ MES, $200 \mathrm{mM}$ acetosyringone). The bacterial suspensions were incubated at room temperature for 1 to $3 \mathrm{~h}$, and agroinfiltration using a needle-less syringe was performed on the abaxial side of 3- to 5-week-old $N$. benthamiana leaves at a final optical density at $600 \mathrm{~nm}$ of 0.3 to 0.5 . Cell death or suppression of cell death were monitored for 4 to 5 days and were visually quantified after 5 days.

\section{ACKNOWLEDGMENTS}

Support was provided by the National Science Foundation grant numbers IOS-0744875 and IOS-1353366 and by Agriculture and Food Research Initiative Competitive grant number 224426 from the United States Department of Agriculture National Institute of Food and Agriculture.

\section{LITERATURE CITED}

Adhikari, B. N., Hamilton, J. P., Zerillo, M. M., Tisserat, N., Lévesque, C. A., and Buell, C. R. 2013. Comparative genomics reveals insight into virulence strategies of plant pathogenic oomycetes. PLoS One 8:e75072. 
Alfano, J. R. 2009. Roadmap for future research on plant pathogen effectors. Mol. Plant Pathol. 10:805-813.

Alfano, J. R., Charkowski, A. O., Deng, W. L., Badel, J. L., Petnicki-Ocwieja, T., van Dijk, K., and Collmer, A. 2000. The Pseudomonas syringae Hrp pathogenicity island has a tripartite mosaic structure composed of a cluster of type III secretion genes bounded by exchangeable effector and conserved effector loci that contribute to parasitic fitness and pathogenicity in plants. Proc. Natl. Acad. Sci. U.S.A. 97:4856-4861.

Allen, R. L., Bittner-Eddy, P. D., Grenville-Briggs, L. J., Meitz, J. C., Rehmany, A. P., Rose, L. E., and Beynon, J. L. 2004. Host-parasite coevolutionary conflict between Arabidopsis and downy mildew. Science 306:1957-1960.

Anderson, R. G., Casady, M. S., Fee, R. A., Vaughan, M. M., Deb, D., Fedkenheuer, K., Huffaker, A., Schmelz, E. A., Tyler, B. M., and McDowell, J. M. 2012. Homologous RXLR effectors from Hyaloperonospora arabidopsidis and Phytophthora sojae suppress immunity in distantly related plants. Plant J. 72:882-893.

Anderson, R. G., Deb, D., Fedkenheuer, K., and McDowell, J. M. 2015 Recent progress in RXLR effector research. Mol. Plant-Microbe Interact. 28:1063-1072.

Baxter, L., Tripathy, S., Ishaque, N., Boot, N., Cabral, A., Kemen, E., Thines, M., Ah-Fong, A., Anderson, R., Badejoko, W., Bittner-Eddy, P., Boore, J. L., Chibucos, M. C., Coates, M., Dehal, P., Delehaunty, K., Dong, S., Downton, P., Dumas, B., Fabro, G., Fronick, C., Fuerstenberg, S. I., Fulton, L., Gaulin, E., Govers, F., Hughes, L., Humphray, S., Jiang, R. H. Y., Judelson, H., Kamoun, S., Kyung, K., Meijer, H., Minx, P., Morris, P., Nelson, J., Phuntumart, V., Qutob, D., Rehmany, A., RougonCardoso, A., Ryden, P., Torto-Alalibo, T., Studholme, D., Wang, Y., Win, J., Wood, J., Clifton, S. W., Rogers, J., Van den Ackerveken, G., Jones, J. D. G., McDowell, J. M., Beynon, J., and Tyler, B. M. 2010. Signatures of adaptation to obligate biotrophy in the Hyaloperonospora arabidopsidis genome. Science 330:1549-1551.

Birch, P. R., Rehmany, A. P., Pritchard, L., Kamoun, S., and Beynon, J. L. 2006. Trafficking arms: Oomycete effectors enter host plant cells. Trends Microbiol. 14:8-11

Boller, T., and Felix, G. 2009. A renaissance of elicitors: Perception of microbe-associated molecular patterns and danger signals by patternrecognition receptors. Annu. Rev. Plant Biol. 60:379-406.

Bos, J. I., Armstrong, M. R., Gilroy, E. M., Boevink, P. C., Hein, I., Taylor, R. M., Zhendong, T., Engelhardt, S., Vetukuri, R. R., Harrower, B., Dixelius, C., Bryan, G., Sadanandom, A., Whisson, S. C., Kamoun, S. and Birch, P. R. 2010. Phytophthora infestans effector AVR3a is essential for virulence and manipulates plant immunity by stabilizing host E3 ligase CMPG1. Proc. Natl. Acad. Sci. U.S.A. 107:9909-9914.

Bos, J. I., Kanneganti, T. D., Young, C., Cakir, C., Huitema, E., Win, J., Armstrong, M. R., Birch, P. R., and Kamoun, S. 2006. The C-terminal half of Phytophthora infestans RXLR effector AVR3a is sufficient to trigger R3a-mediated hypersensitivity and suppress INF1-induced cell death in Nicotiana benthamiana. Plant J. 48:165-176.

Boutemy, L. S., King, S. R., Win, J., Hughes, R. K., Clarke, T. A., Blumenschein, T. M., Kamoun, S., and Banfield, M. J. 2011. Structures of Phytophthora RXLR effector proteins: A conserved but adaptable fold underpins functional diversity. J. Biol. Chem. 286:35834-35842.

Cabral, A., Stassen, J. H., Seidl, M. F., Bautor, J., Parker, J. E., and Van den Ackerveken, G. 2011. Identification of Hyaloperonospora arabidopsidis transcript sequences expressed during infection reveals isolate-specific effectors. PLoS One 6:e19328.

Caillaud, M. C., Wirthmueller, L., Fabro, G., Piquerez, S. J., Asai, S., Ishaque, N., and Jones, J. D. 2012. Mechanisms of nuclear suppression of host immunity by effectors from the Arabidopsis downy mildew pathogen Hyaloperonospora arabidopsidis (Hpa). Cold Spring Harb. Symp. Quant. Biol. 77:285-293.

Chang, J. H., Desveaux, D., and Creason, A. L. 2014. The ABCs and 123s of bacterial secretion systems in plant pathogenesis. Annu. Rev. Phytopathol 52:317-345.

Chisholm, S. T., Coaker, G., Day, B., and Staskawicz, B. J. 2006. Hostmicrobe interactions: Shaping the evolution of the plant immune response. Cell 124:803-814

Clough, S. J., and Bent, A. F. 1998. Floral dip: A simplified method for Agrobacterium-mediated transformation of Arabidopsis thaliana. Plant J. 16 : 735-743

Coates, M. E., and Beynon, J. L. 2010. Hyaloperonospora arabidopsidis as a pathogen model. Annu. Rev. Phytopathol. 48:329-345.

Collmer, A., Badel, J. L., Charkowski, A. O., Deng, W. L., Fouts, D. E., Ramos, A. R., Rehm, A. H., Anderson, D. M., Schneewind, O., van Dijk, K., and Alfano, J. R. 2000. Pseudomonas syringae Hrp type III secretion system and effector proteins. Proc. Natl. Acad. Sci. U.S.A. 97:8770-8777.

Couto, D., and Zipfel, C. 2016. Regulation of pattern recognition receptor signalling in plants. Nat. Rev. Immunol. 16:537-552.
Cui, H., Tsuda, K., and Parker, J. E. 2015. Effector-triggered immunity: From pathogen perception to robust defense. Annu. Rev. Plant Biol. 66: 487-511.

Cumbie, J. S., Pankow, R. C., Thomas, W. J., and Chang, J. H. 2011. AutoSPOTs: Automated image analysis for enumerating callose deposition Presented at the Genome-Enabled Integration of Research in Plant Pathogen Systems, 10th Japan-US Seminar, Corvallis, Oregon on January 24-28, 2010 T. J. Wolpert, T. Shiraishe, A. Collmer, K. Akimitsu, and J. Glazebrook, eds. American Phytopathological Society, St. Paul, MN, U.S.A.

de Jonge, R., van Esse, H. P., Kombrink, A., Shinya, T., Desaki, Y., Bours, R., van der Krol, S., Shibuya, N., Joosten, M. H. A. J., and Thomma, B. P. H. J. 2010. Conserved fungal LysM effector Ecp6 prevents chitintriggered immunity in plants. Science 329:953-955.

DebRoy, S., Thilmony, R., Kwack, Y. B., Nomura, K., and He, S. Y. 2004. A family of conserved bacterial effectors inhibits salicylic acid-mediated basal immunity and promotes disease necrosis in plants. Proc. Natl. Acad. Sci. U.S.A. 101:9927-9932.

Dodds, P. N., and Rathjen, J. P. 2010. Plant immunity: Towards an integrated view of plant-pathogen interactions. Nat. Rev. Genet. 11:539-548.

Dou, D., Kale, S. D., Liu, T., Tang, Q., Wang, X., Arredondo, F. D. Basnayake, S., Whisson, S., Drenth, A., Maclean, D., and Tyler, B. M 2010. Different domains of Phytophthora sojae effector Avr4/6 are recognized by soybean resistance genes Rps 4 and Rps6. Mol. PlantMicrobe Interact. 23:425-435.

Dou, D., Kale, S. D., Wang, X., Chen, Y., Wang, Q., Wang, X., Jiang, R. H., Arredondo, F. D., Anderson, R. G., Thakur, P. B., McDowell, J. M., Wang, Y., and Tyler, B. M. 2008. Conserved C-terminal motifs required for avirulence and suppression of cell death by Phytophthora sojae effector Avr1b. Plant Cell 20:1118-1133.

Erwin, D. C., and Ribiero, O. K. 1996. Phytophthora Diseases Worldwide. APS Press, St. Paul, Minnesota.

Eulgem, T., Tsuchiya, T., Wang, X. J., Beasley, B., Cuzick, A., Tör, M., Zhu, T., McDowell, J. M., Holub, E., and Dangl, J. L. 2007. EDM2 is required for $R P P 7$-dependent disease resistance in Arabidopsis and affects $R P P 7$ transcript levels. Plant J. 49:829-839.

Fabro, G., Steinbrenner, J., Coates, M., Ishaque, N., Baxter, L., Studholme, D. J., Körner, E., Allen, R. L., Piquerez, S. J., Rougon-Cardoso, A., Greenshields, D., Lei, R., Badel, J. L., Caillaud, M. C., Sohn, K. H., Van den Ackerveken, G., Parker, J. E., Beynon, J., and Jones, J. D. 2011 Multiple candidate effectors from the oomycete pathogen Hyaloperonospora arabidopsidis suppress host plant immunity. PLoS Pathog. 7: e1002348.

Feng, F., and Zhou, J.-M. 2012. Plant-bacterial pathogen interactions mediated by type III effectors. Curr. Opin. Plant Biol. 15:469-476.

Förster, H., Tyler, B. M., and Coffey, M. D. 1994. Phytophthora sojae races have arisen by clonal evolution and by rare outcrosses. Mol. PlantMicrobe Interact. 7:780-791.

Fry, W. 2008. Phytophthora infestans: The plant (and $R$ gene) destroyer. Mol. Plant Pathol. 9:385-402.

Gisi, U. 2002. chemical control of downy mildews. Pages 119-159 in: Advances in Downy Mildew Research. U. Gisi, and A. Lebeda, eds. Kluwer Academic Publishers, Dordrecht, NE.

González-Lamothe, R., Tsitsigiannis, D. I., Ludwig, A. A., Panicot, M., Shirasu, K., and Jones, J. D. G. 2006. The U-box protein CMPG1 is required for efficient activation of defense mechanisms triggered by multiple resistance genes in tobacco and tomato. Plant Cell 18:1067-1083.

Goritschnig, S., Krasileva, K. V., Dahlbeck, D., and Staskawicz, B. J. 2012. Computational prediction and molecular characterization of an oomycete effector and the cognate Arabidopsis resistance gene. PLoS Genet. 8:e1002502.

Haas, B. J., Kamoun, S., Zody, M. C., Jiang, R. H., Handsaker, R. E., Cano, L. M., Grabherr, M., Kodira, C. D., Raffaele, S., Torto-Alalibo, T., Bozkurt, T. O., Ah-Fong, A. M., Alvarado, L., Anderson, V. L., Armstrong, M. R., Avrova, A., Baxter, L., Beynon, J., Boevink, P. C., Bollmann, S. R., Bos, J. I., Bulone, V., Cai, G., Cakir, C., Carrington, J. C., Chawner, M., Conti, L., Costanzo, S., Ewan, R., Fahlgren, N., Fischbach, M. A., Fugelstad, J., Gilroy, E. M., Gnerre, S., Green, P. J. Grenville-Briggs, L. J., Griffith, J., Grünwald, N. J., Horn, K., Horner, N. R., Hu, C. H., Huitema, E., Jeong, D. H., Jones, A. M., Jones, J. D., Jones, R. W., Karlsson, E. K., Kunjeti, S. G., Lamour, K., Liu, Z., Ma, L., Maclean, D., Chibucos, M. C., McDonald, H., McWalters, J., Meijer, H. J., Morgan, W., Morris, P. F., Munro, C. A., O’Neill, K., OspinaGiraldo, M., Pinzón, A., Pritchard, L., Ramsahoye, B., Ren, Q., Restrepo, S., Roy, S., Sadanandom, A., Savidor, A., Schornack, S. Schwartz, D. C., Schumann, U. D., Schwessinger, B., Seyer, L., Sharpe, T., Silvar, C., Song, J., Studholme, D. J., Sykes, S., Thines, M., van de Vondervoort, P. J., Phuntumart, V., Wawra, S., Weide, R., Win, J., Young, C., Zhou, S., Fry, W., Meyers, B. C., van West, P., Ristaino, J., Govers, F., Birch, P. R., Whisson, S. C., Judelson, H. S., and Nusbaum, C. 2009. 
Genome sequence and analysis of the Irish potato famine pathogen Phytophthora infestans. Nature 461:393-398.

Harris, C. J., Slootweg, E. J., Goverse, A., and Baulcombe, D. C. 2013. Stepwise artificial evolution of a plant disease resistance gene. Proc. Natl. Acad. Sci. U.S.A. 110:21189-21194.

Hauck, P., Thilmony, R., and He, S. Y. 2003. A Pseudomonas syringae type III effector suppresses cell wall-based extracellular defense in susceptible Arabidopsis plants. Proc. Natl. Acad. Sci. U.S.A. 100:8577-8582.

Hogenhout, S. A., Van der Hoorn, R. A., Terauchi, R., and Kamoun, S. 2009. Emerging concepts in effector biology of plant-associated organisms. Mol. Plant-Microbe Interact. 22:115-122.

Holub, E. B. 2008. Natural history of Arabidopsis thaliana and oomycete symbioses. Eur. J. Plant Pathol. 122:91-109.

Jiang, R. H., Tripathy, S., Govers, F., and Tyler, B. M. 2008. RXLR effector reservoir in two Phytophthora species is dominated by a single rapidly evolving superfamily with more than 700 members. Proc. Natl. Acad. Sci. U.S.A. 105:4874-4879.

Jiang, R. H., and Tyler, B. M. 2012. Mechanisms and evolution of virulence in oomycetes. Annu. Rev. Phytopathol. 50:295-318.

Jones, J. D., and Dangl, J. L. 2006. The plant immune system. Nature 444: 323-329.

Kale, S. D., and Tyler, B. M. 2011. Assaying effector function in planta using double-barreled particle bombardment. Methods Mol. Biol. 712:153-172.

Kamoun, S. 2006. A catalogue of the effector secretome of plant pathogenic oomycetes. Annu. Rev. Phytopathol. 44:41-60.

Kamoun, S., Furzer, O., Jones, J. D., Judelson, H. S., Ali, G. S., Dalio, R. J., Roy, S. G., Schena, L., Zambounis, A., Panabières, F., Cahill, D., Ruocco, M., Figueiredo, A., Chen, X. R., Hulvey, J., Stam, R., Lamour, K., Gijzen, M., Tyler, B. M., Grünwald, N. J., Mukhtar, M. S., Tomé, D. F., Tör, M., Van Den Ackerveken, G., McDowell, J., Daayf, F., Fry, W. E., Lindqvist-Kreuze, H., Meijer, H. J., Petre, B., Ristaino, J., Yoshida, K., Birch, P. R., and Govers, F. 2015. The Top 10 oomycete pathogens in molecular plant pathology. Mol. Plant Pathol. 16:413-434.

Karimi, M., Inzé, D., and Depicker, A. 2002. GATEWAY vectors for Agrobacterium-mediated plant transformation. Trends Plant Sci. 7:193-195.

Lamour, K. H., Mudge, J., Gobena, D., Hurtado-Gonzales, O. P., Schmutz, J., Kuo, A., Miller, N. A., Rice, B. J., Raffaele, S., Cano, L. M., Bharti, A. K., Donahoo, R. S., Finley, S., Huitema, E., Hulvey, J., Platt, D., Salamov, A., Savidor, A., Sharma, R., Stam, R., Storey, D., Thines, M., Win, J., Haas, B. J., Dinwiddie, D. L., Jenkins, J., Knight, J. R., Affourtit, J. P., Han, C. S., Chertkov, O., Lindquist, E. A., Detter, C., Grigoriev, I. V., Kamoun, S., and Kingsmore, S. F. 2012. Genome sequencing and mapping reveal loss of heterozygosity as a mechanism for rapid adaptation in the vegetable pathogen Phytophthora capsici. Mol. PlantMicrobe Interact. 25:1350-1360.

Lévesque, C. A., Brouwer, H., Cano, L., Hamilton, J. P., Holt, C., Huitema E., Raffaele, S., Robideau, G. P., Thines, M., Win, J., Zerillo, M. M., Beakes, G. W., Boore, J. L., Busam, D., Dumas, B., Ferriera, S., Fuerstenberg, S. I., Gachon, C. M., Gaulin, E., Govers, F., GrenvilleBriggs, L., Horner, N., Hostetler, J., Jiang, R. H., Johnson, J., Krajaejun, T., Lin, H., Meijer, H. J., Moore, B., Morris, P., Phuntmart, V., Puiu, D., Shetty, J., Stajich, J. E., Tripathy, S., Wawra, S., van West, P., Whitty, B. R., Coutinho, P. M., Henrissat, B., Martin, F., Thomas, P. D., Tyler, B. M., De Vries, R. P., Kamoun, S., Yandell, M., Tisserat, N., and Buell, C. R. 2010. Genome sequence of the necrotrophic plant pathogen Pythium ultimum reveals original pathogenicity mechanisms and effector repertoire. Genome Biol. 11:R73.

Lucas, J., Hayter, J., and Crute, I. 1995. The downy mildews: Host specificity and pathogenesis. Pages 217-234 in: Pathogenesis and Host Specificity in Plant Diseases. Singh, U., and Singh, R., eds. Permagon,Oxford.

Ma, Z., Song, T., Zhu, L., Ye, W., Wang, Y., Shao, Y., Dong, S., Zhang, Z., Dou, D., Zheng, X., Tyler, B. M., and Wang, Y. 2015. A Phytophthora sojae glycoside hydrolase 12 protein is a major virulence factor during soybean infection and is recognized as a PAMP. Plant Cell 27: 2057-2072.

Macho, A. P., and Zipfel, C. 2014. Plant PRRs and the activation of innate immune signaling. Mol. Cell 54:263-272.

McDowell, J. M. 2014. Hyaloperonospora arabidopsidis: A model pathogen of Arabidopsis. Pages209-234 in: Genomics of Plant-Associated Fungi and Oomcyetes: Dicot Pathogens, R. A. Dean, C. Kole, and A. Lichens-Park, eds. Springer, New York.

McDowell, J. M., Hoff, T., Anderson, R. G., and Deegan, D. 2011. Propagation, storage, and assays with Hyaloperonospora arabidopsidis: A model oomycete pathogen of Arabidopsis. Methods Mol. Biol. 712: 137-151.

McLellan, H., Boevink, P. C., Armstrong, M. R., Pritchard, L., Gomez, S., Morales, J., Whisson, S. C., Beynon, J. L., and Birch, P. R. 2013. An RxLR effector from Phytophthora infestans prevents re-localisation of two plant NAC transcription factors from the endoplasmic reticulum to the nucleus. PLoS Pathog 9:e1003670.

Mukhtar, M. S., Carvunis, A. R., Dreze, M., Epple, P., Steinbrenner, J., Moore, J., Tasan, M., Galli, M., Hao, T., Nishimura, M. T., Pevzner, S. J., Donovan, S. E., Ghamsari, L., Santhanam, B., Romero, V., Poulin, M. M., Gebreab, F., Gutierrez, B. J., Tam, S., Monachello, D., Boxem, M., Harbort, C. J., McDonald, N., Gai, L., Chen, H., He, Y. Vandenhaute, J., Roth, F. P., Hill, D. E., Ecker, J. R., Vidal, M., Beynon, J., Braun, P., and Dangl, J. L., European Union Effectoromics Consortium. 2011. Independently evolved virulence effectors converge onto hubs in a plant immune system network. Science 333:596-601.

Munkvold, K. R., and Martin, G. B. 2009. Advances in experimental methods for the elucidation of Pseudomonas syringae effector function with a focus on AvrPtoB. Mol. Plant Pathol. 10:777-793.

Nomura, K., Debroy, S., Lee, Y. H., Pumplin, N., Jones, J., and He, S. Y. 2006. A bacterial virulence protein suppresses host innate immunity to cause plant disease. Science 313:220-223.

Petre, B., and Kamoun, S. 2014. How do filamentous pathogens deliver effector proteins into plant cells? PLoS Biol. 12:e1001801.

Qutob, D., Kemmerling, B., Brunner, F., Küfner, I., Engelhardt, S., Gust, A. A., Luberacki, B., Seitz, H. U., Stahl, D., Rauhut, T., Glawischnig, E., Schween, G., Lacombe, B., Watanabe, N., Lam, E., Schlichting, R., Scheel, D., Nau, K., Dodt, G., Hubert, D., Gijzen, M., and Nürnberger, T. 2006. Phytotoxicity and innate immune responses induced by Nep1-like proteins. Plant Cell 18:3721-3744.

Rehmany, A. P., Gordon, A., Rose, L. E., Allen, R. L., Armstrong, M. R., Whisson, S. C., Kamoun, S., Tyler, B. M., Birch, P. R., and Beynon, J. L. 2005. Differential recognition of highly divergent downy mildew avirulence gene alleles by $R P P 1$ resistance genes from two Arabidopsis lines. Plant Cell 17:1839-1850.

Savory, E. A., Adhikari, B. N., Hamilton, J. P., Vaillancourt, B., Buell, C. R., and Day, B. 2012. mRNA-Seq analysis of the Pseudoperonospora cubensis transcriptome during cucumber (Cucumis sativus L.) infection. PLoS One 7:e35796.

Segretin, M. E., Pais, M., Franceschetti, M., Chaparro-Garcia, A., Bos, J. I., Banfield, M. J., and Kamoun, S. 2014. Single amino acid mutations in the potato immune receptor R3a expand response to Phytophthora effectors. Mol. Plant-Microbe Interact. 27:624-637.

Sohn, K. H., Lei, R., Nemri, A., and Jones, J. D. 2007. The downy mildew effector proteins ATR1 and ATR13 promote disease susceptibility in Arabidopsis thaliana. Plant Cell 19:4077-4090.

Thatcher, L. F., Gardiner, D. M., Kazan, K., and Manners, J. M. 2012. A highly conserved effector in Fusarium oxysporum is required for full virulence on Arabidopsis. Mol. Plant-Microbe Interact. 25:180-190.

Thines, M. 2014. Phylogeny and evolution of plant pathogenic oomycetes-A global overview. Eur. J. Plant Pathol. 138:431-447.

Thomas, W. J., Thireault, C. A., Kimbrel, J. A., and Chang, J. H. 2009. Recombineering and stable integration of the Pseudomonas syringae pv syringae $61 \mathrm{hrp} / \mathrm{hrc}$ cluster into the genome of the soil bacterium Pseudomonas fluorescens Pf0-1. Plant J. 60:919-928.

Tian, M., Win, J., Savory, E., Burkhardt, A., Held, M., Brandizzi, F., and Day, B. 2011. 454 Genome sequencing of Pseudoperonospora cubensis reveals effector proteins with a QXLR translocation motif. Mol. PlantMicrobe Interact. 24:543-553.

Torto, T. A., Li, S., Styer, A., Huitema, E., Testa, A., Gow, N. A., van West, P., and Kamoun, S. 2003. EST mining and functional expression assays identify extracellular effector proteins from the plant pathogen Phytophthora. Genome Res. 13:1675-1685.

Toruño, T. Y., Stergiopoulos, I., and Coaker, G. 2016. Plant-pathogen effectors: Cellular probes interfering with plant defenses in spatial and temporal manners. Annu. Rev. Phytopathol. 54:419-441.

Tyler, B. M., Tripathy, S., Zhang, X., Dehal, P., Jiang, R. H., Aerts, A., Arredondo, F. D., Baxter, L., Bensasson, D., Beynon, J. L., Chapman, J., Damasceno, C. M., Dorrance, A. E., Dou, D., Dickerman, A. W., Dubchak, I. L., Garbelotto, M., Gijzen, M., Gordon, S. G., Govers, F., Grunwald, N. J., Huang, W., Ivors, K. L., Jones, R. W., Kamoun, S., Krampis, K., Lamour, K. H., Lee, M. K., McDonald, W. H., Medina, M., Meijer, H. J., Nordberg, E. K., Maclean, D. J., Ospina-Giraldo, M. D., Morris, P. F., Phuntumart, V., Putnam, N. H., Rash, S., Rose, J. K., Sakihama, Y., Salamov, A. A., Savidor, A., Scheuring, C. F., Smith, B. M., Sobral, B. W., Terry, A., Torto-Alalibo, T. A., Win, J., Xu, Z., Zhang, H., Grigoriev, I. V., Rokhsar, D. S., and Boore, J. L. 2006. Phytophthora genome sequences uncover evolutionary origins and mechanisms of pathogenesis. Science 313:1261-1266.

van der Biezen, E. A., Freddie, C. T., Kahn, K., Parker, J. E., and Jones, J. D. 2002. Arabidopsis RPP4 is a member of the RPP5 multigene family of TIR-NB-LRR genes and confers downy mildew resistance through multiple signalling components. Plant J. 29:439-451. 
van der Hoorn, R. A., and Kamoun, S. 2008. From guard to decoy: A new model for perception of plant pathogen effectors. Plant Cell 20:2009-2017.

Van der Hoorn, R. A., Laurent, F., Roth, R., and De Wit, P. J. 2000. Agroinfiltration is a versatile tool that facilitates comparative analyses of Avr9/Cf-9-induced and Avr4/Cf-4-induced necrosis. Mol. Plant-Microbe Interact. 13:439-446.

Vleeshouwers, V. G., and Oliver, R. P. 2014. Effectors as tools in disease resistance breeding against biotrophic, hemibiotrophic, and necrotrophic plant pathogens. Mol. Plant-Microbe Interact. 27:196-206.

Wang, Q., Han, C., Ferreira, A. O., Yu, X., Ye, W., Tripathy, S., Kale, S. D., Gu, B., Sheng, Y., Sui, Y., Wang, X., Zhang, Z., Cheng, B., Dong, S., Shan, W., Zheng, X., Dou, D., Tyler, B. M., and Wang, Y. 2011. Transcriptional programming and functional interactions within the Phytophthora sojae RXLR effector repertoire. Plant Cell 23:2064-2086.

Wang, S., Boevink, P. C., Welsh, L., Zhang, R., Whisson, S. C., and Birch, P. R. J. 2017. Delivery of cytoplasmic and apoplastic effectors from Phytophthora infestans haustoria by distinct secretion pathways. New Phytol. 216:205-215.

Weßling, R., Epple, P., Altmann, S., He, Y., Yang, L., Henz, S. R., McDonald, N., Wiley, K., Bader, K. C., Gläßer, C., Mukhtar, M. S., Haigis, S., Ghamsari, L., Stephens, A. E., Ecker, J. R., Vidal, M., Jones,
J. D., Mayer, K. F., Ver Loren van Themaat, E., Weigel, D., SchulzeLefert, P., Dangl, J. L., Panstruga, R., and Braun, P. 2014. Convergent targeting of a common host protein-network by pathogen effectors from three kingdoms of life. Cell Host Microbe 16:364-375.

Whisson, S. C., Boevink, P. C., Moleleki, L., Avrova, A. O., Morales, J. G., Gilroy, E. M., Armstrong, M. R., Grouffaud, S., van West, P., Chapman, S., Hein, I., Toth, I. K., Pritchard, L., and Birch, P. R. 2007. A translocation signal for delivery of oomycete effector proteins into host plant cells. Nature 450:115-118.

Win, J., Krasileva, K. V., Kamoun, S., Shirasu, K., Staskawicz, B. J., and Banfield, M. J. 2012. Sequence divergent RXLR effectors share a structural fold conserved across plant pathogenic oomycete species. PLoS Pathog. 8:e1002400.

Ye, W., Wang, Y., Shen, D., Li, D., Pu, T., Jiang, Z., Zhang, Z., Zheng, X., Tyler, B. M., and Wang, Y. 2016. Sequencing of the Litchi downy blight pathogen reveals it is a Phytophthora species with downy mildew-like characteristics. Mol. Plant-Microbe Interact. 29:573-583.

Yuan, J., and He, S. Y. 1996. The Pseudomonas syringae Hrp regulation and secretion system controls the production and secretion of multiple extracellular proteins. J. Bacteriol. 178:6399-6402. 